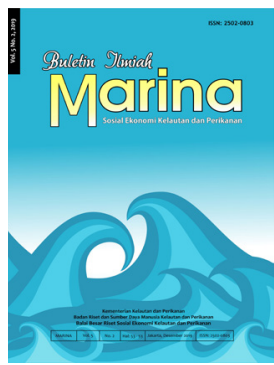

BULETIN ILMIAH MARINA

SOSIAL EKONOMI KELAUTAN DAN PERIKANAN

http://ejournal-balitbang.kkp.go.id/index.php/mra

p-ISSN: 2502-0803

e-ISSN: 2541-2930

Nomor Akreditasi: 10/E/KPT/2019

\title{
PEMBANGUNAN PERIKANAN BUDI DAYA NASIONAL: KINERJA DAN PERSPEKTIF PENINGKATAN EFISIENSI DAN PRODUKTIVITAS BERBASIS EKOSISTEM
}

\section{National Aquaculture Development: The Performance and Perspective of Improving Efficiency and Productivity Based on Ecosystem}

\author{
*Andy A. D. Oktopura',Akhmad Fauzi', Ketut Sugama², dan Heti Mulyati ${ }^{1}$ \\ ${ }^{1}$ Fakultas Ekonomi dan Manajemen, IPB University \\ JI. Raya Dramaga Kampus, IPB Dramaga Bogor, 16680 Jawa Barat, Indonesia \\ ${ }^{2}$ Kementerian Kelautan dan Perikanan \\ JI. Medan Merdeka Timur, Jakarta Pusat, DKI Jakarta, Indonesia \\ Diterima tanggal: 6 April 2020 Diterima setelah perbaikan: 29 Mei 2020 \\ Disetujui terbit: 26 Juni 2020
}

\begin{abstract}
ABSTRAK
Peningkatan jumlah populasi penduduk yang diikuti dengan perlambatan ekonomi dan stagnasi stok dan volume produksi perikanan tangkap menjadi masalah dalam perekonomian nasional. Perikanan budi daya diharapkan menjadi salah satu alternatif penggerak perekonomian nasional di masa datang. Penelitian ini bertujuan untuk mengidentifikasi isu dan permasalahan serta menganalisis kinerja pembangunan perikanan budi daya nasional berdasarkan tipologi ekosistem budi daya. Penelitian ini dilakukan di 17 provinsi yang memiliki kontribusi lebih dari lima puluh persen produksi nasional, yang didasarkan pada 3 (tiga) ekosistem, yaitu; air payau, air laut, dan air tawar. Metode analisis yang digunakan untuk menganalisa efisiensi dan produktivitas adalah Data Envelopment Analysis (DEA). Data yang digunakan dalam penelitian ini adalah data primer dan sekunder yang bersumber dari forum grup diskusi dan data stastitik. Data luas lahan dan jumlah pembudi daya digunakan sebagai input sedangkan volume produksi dan indeks penerimaan pembudi daya ikan sebagai output. Hasil penelitian menunjukkan bahwa isu dan permasalahan perikanan budi daya bersifat multi dimensi yang dipengaruhi oleh aspek ekologi, ekonomi, dan sosial. Hasil perhitungan nilai efisiensi dan nilai indek Malmquist menunjukkan bahwa masih terjadi inefisiensi pada pembangunan perikanan budi daya nasional, meskipun secara rata-rata terjadi peningkatan produktivitas relatif di masing-masing tipologi ekosistem, yaitu air laut, air payau, dan air tawar rata-rata sebesar $8 \%, 13 \%$, dan $12 \%$. Penelitian ini menyimpulkan bahwa kinerja pembangunan perikanan budi daya nasional belum optimal selama tahun $2013-2017$, tetapi berpotensi untuk ditingkatkan di masa datang apabila didukung dengan implementasi kebijakan yang memperkuat efisiensi manajemen sistem produksi dan pengembangan inovasi teknologi.
\end{abstract}

Kata Kunci: kinerja pembangunan; DEA; efisiensi; indeks malmquist; perikanan budi daya; produktivitas

\begin{abstract}
Increased population, deceleration in economic growth, stagnation in fish stock and volume of capture fisheries has been the problems in national economy. Therefore, aquaculture is expected to be an alternative driving force of future national economy. This study aimed at identifying issues and problems as well as analyzing performance of national aquaculture development based on the typology of its cultivation ecosystem. This research was conducted in 17 provinces that contributed more than fifty percent of national production based on 3 (three) ecosystems, namely; brackish water, sea water, and fresh water. Data Envelopment Analysis (DEA) method was used to analyze the efficiency and productivity of national aquaculture performance. This study used primary and secondary data from discussion group and statistical data. The inputs of the research included data of land area and the
\end{abstract}


number of aquaculture farmers, while the outputs included production volume and fish farmers income index. The results show that the aquaculture issues were multidimensional in nature which were influenced by ecological, economic and social aspects. The calculation of efficiency and Malmquist index indicate that inefficiencies yet occured in the development of national aquaculture, although the relative productivity increased in each ecosystem typologies, namely sea water, brackish water, and fresh water with average number of $8 \%, 13 \%$ and $12 \%$. This study concluded that national aquaculture development had not been in optimal performance during 2013 - 2017, but the performance could be potentially improved in the future if it is reinforced with the implementation of proper policies that strengthen the efficiency of production management and enhancement of technological innovations.

\section{Keywords: development performance; DEA; efficiency; malmquist index; aquaculture; productivity}

\section{PENDAHULUAN}

Peningkatan jumlah populasi penduduk Indonesia dengan laju pertumbuhan rata-rata diproyeksikan $1,03 \%$ per tahun atau mencapai 296,4 juta orang pada tahun 2030 akan berbanding lurus dengan peningkatan permintaan ikan untuk konsumsi penduduk dan kebutuhan lapangan pekerjaan (BPS, 2019). Perikanan budi daya merupakan salah satu sub sektor yang dapat menjadi alternatif sumber devisa negara dan ketahanan pangan nasional. Menurut Dahuri (2018), potensi produksi perikanan budi daya di Indonesia mencapai 100 juta ton/tahun dengan nilai produksi mencapai US\$251 miliar. Kontribusi sub sektor perikanan budi daya terhadap total nilai ekspor non migas adalah $1,13 \%$, dan $37,71 \%$ jika dibandingkan terhadap total nilai ekspor perikanan pada tahun 2018 (BPS, 2019). Data tersebut menunjukkan bahwa perikanan budi daya masih memberikan kontribusi positif terhadap neraca perdagangan nasional dan pertumbuhan ekonomi nasional meskipun ada perlambatan ekonomi global dan defisit neraca perdagangan pada tahun 2017 - 2018. Hal Ini membuktikan bahwa perikanan budi daya mempunyai daya tahan yang baik terhadap perubahan ekonomi global. Kontribusi sektor perikanan budi daya terhadap ketahanan pangan nasional dapat dilihat dari peningkatan laju pertumbuhan produksi total ikan di Indonesia. Peningkatan rata-rata produksi sebesar 15,95 $\%$, yaitu dari volume produksi 1,08 juta ton pada tahun 2007 menjadi 4,59 juta ton pada tahun 2017 (KKP, 2018a). Salah satu faktor pendorong sub sektor perikanan budi daya sebagai salah satu pilar ekonomi di Indonesia pada masa mendatang adalah ketersediaan potensi lahan perikanan budi daya di Indonesia yang mencapai 17,92 juta hektare, yang terdiri 2,8 juta hektare lahan perikanan budi daya air tawar dengan pemanfaatannya $11,2 \%$; 2,9 juta hektare tambak dengan pemanfaatannya mencapai $20,4 \%$; dan potensi budi daya laut 12,1 juta hektare dengan pemanfaatannya mencapai $2,3 \%$, sehingga pemanfaatan rata-ratanya baru mencapai $6,7 \%$ (KKP, 2018b).

Penelitian yang telah dilakukan di berbagai wilayah menunjukkan bahwa pembangunan sub sektor perikanan budi daya di masa mendatang menjadi kunci dalam menyediakan pasokan ikan dalam sistem perikanan untuk ketahanan pangan (nasional, regional, dan dunia), menciptakan lapangan pekerjaan, pertumbuhan ekonomi, serta sumber devisa negara (FAO, 2016; Phillips et al., 2016; Suryana, Fauzi, Juanda, \& Rustiadi, 2014; Fauzi, 2010; Hishamunda, Cai, \& Leung, 2009; World Bank, 2007; Tacon, 2001). Menurut Suryana et al. (2014), kontribusi perikanan budi daya terhadap pembangunan ekonomi nasional di masa datang mempunyai peran yang sangat strategis, sehingga perlu dioptimalkan dan dilakukan peningkatan produktivitas. Produktivitas merupakan salah satu faktor penting penentu pertumbuhan ekonomi di sub sektor perikanan budi daya. Menurut Asche, Roll, \& Tveteras (2007), produktivitas merupakan sumber pertumbuhan pada komoditas perikanan yang produksinya meningkat signifikan. Menurut Juarno, Oktaviani, Fauzi, \& Nuryartono (2011), indikator pengukuran efisiensi dan produktivitas pembangunan perikanan budi daya, khususnya untuk komoditas udang dapat menggunakan pendekatan Total Faktor Produksi (TFP). Permasalahan yang dihadapi dalam peningkatan efisiensi dan produktivitas sub sektor perikanan budi daya adalah tingkat pemanfaatan lahan dan produktivitas usaha yang masih rendah, ketersediaan sarana produksi yang bermutu dan berkualitas, nilai tambah ekonomi yang masih relatif kecil, karakteristik pelaku usaha perikanan budi daya yang didominasi oleh pembudi daya skala kecil dengan tingkat 
pengetahuan teknologi yang terbatas, keterbatasan akses permodalan bagi pelaku usaha, penurunan daya dukung lingkungan, dukungan infrastruktur yang masih minim, adanya asimetris regulasi, dan inkonsistensi kebijakan pembangunan perikanan budi daya secara intra dan antar sektor, serta belum adanya iklim bisnis yang kondusif untuk menjamin investasi yang berkelanjutan (KKP, 2018b).

Ada beberapa pertanyaan yang perlu dijawab dalam penelitian ini, yaitu (1) bagaimana menyusun rencana strategi pembangunan akuakultur yang optimal dan berkelanjutan ke depan secara komprehensif, holistik, efektif, dan efisien; (2) apa saja isu dan tantangan yang dihadapi dalam pengembangan perikanan budi daya di Indonesia; (3) bagaimana atau sejauh mana menganalisis kinerja pembangunan perikanan budi daya yang sudah dilakukan di Indonesia ditinjau dari aspek efisiensi dan produktivitas usaha. Penelitian ini bertujuan untuk mengidentifikasi isu dan permasalahan serta menganalisis kinerja pembangunan perikanan budi daya secara nasional. Penelitian ini dilakukan di tujuh belas provinsi di Indonesia yang memiliki kontribusi lebih dari lima puluh persen produksi nasional dan memiliki potensi semua tipologi ekosistem perikanan budi daya, yaitu air tawar, air payau, dan air laut, yang dilakukan selama bulan September sampai dengan Desember 2019. Data yang digunakan dalam penelitian ini adalah data primer yang bersumber dari diskusi kelompok terfokus serta data sekunder yang bersumber dari data stastistik dan literatur. Diskusi kelompok terfokus melibatkan multi stakeholders, yaitu pemerintah, asosiasi pelaku usaha, dan akademisi. Data hasil diskusi kelompok terfokus dianalisis untuk mengidentifikasi dan merumuskan isu dan tantangan dalam pembangunan perikanan budi daya di masa datang. Data statistik digunakan untuk mengukur efisiensi dan produktivitas kinerja pembangunan perikanan budi daya serta menganalisis dampak kinerja perikanan budi daya terhadap kesejahteraan pembudi daya ikan pada tahun 2013 - 2017. Data input yang digunakan untuk mengukur efisiensi dan produktivitas kinerja adalah luas lahan usaha dan jumlah pembudi daya ikan, sedangkan data output yang digunakan adalah volume produksi dan indeks penerimaan pembudi daya. Ketersediaan data selama periode 2013 - 2017 di semua lokasi penelitian dan semua tipologi ekosistem menjadi pertimbangan utama dalam penentuan variabel input dan output.
Metode analisis yang digunakan untuk mengukur kinerja pembangunan perikanan budi daya adalah metode kuantitatif non parametrik dengan menggunakan Data Envelopment Analysis (DEA) Malmquist. DEA Malmquist berlandaskan pada konsep fungsi produksi dengan batasan input yang sudah ditentukan dan maksimalisasi output pada periode 2013 - 2017. Pengukuran DEA Malmquist menghasilkan tiga keluaran, yaitu indeks malmquist, indeks catch-up, dan indeks frontier shift. Indeks malmquist menggambarkan perubahan total faktor produktivitas relatif dari setiap Decision Making Unit (DMU) pada antar periode waktu. Indeks catch up adalah tingkat perubahan efisiensi relatif dari periode satu ke periode dua pada setiap DMU, sementara frontier shift mengukur tingkat perubahan teknologi yang merupakan kombinasi input dan output dari periode satu ke periode dua pada setiap DMU (Rusydiana, 2018). Aplikasi DEA Malmquist digunakan dalam penelitian ini karena memiliki kemampuan untuk menganalisis dengan multi input dan output, menggambarkan perubahan TFP dari waktu ke waktu, menganalisis tanpa memerlukan ketersediaan data harga dan biaya, menjelaskan hasil perhitungan dari output dan input tanpa perlu menentukan fungsi tujuan perilaku dan memisahkan antara perubahan efisiensi teknis dan perubahan teknologi dari TFP (Charnes, Cooper, \& Rhodes, 1981; Coelli, Rao, O'Donnell, \& Battese, 2005; Farrell, 1957; Fare, Grosskopf, Lindgren, \& Roos, 1994; Alam, 2011; Mustapha, Azis, \& Hashim, 2013; lliyasu et al., 2014, lliyasu, Mohamed, \& Hashim, 2015; Wardono, Fauzi, Fahrudin, \& Purnomo, 2015). Penggunaan DEA dan indeks malmquist untuk analisis produktivitas dan efisensi di sektor perikanan budi daya sudah diterapkan di beberapa penelitian namun masih sangat terbatas (Alam, 2011, lliyasu et al., 2014; Ngoc et al., 2018; Ozbugday, Tirgil, \& Kose, 2019). Alat analisis yang digunakan adalah banxia frontier, karena alat ini mempunyai kemampuan untuk menganalisis tingkat efisiensi dan perubahan produktivitas secara bersama (Hussain \& Jones, 2018).

\section{ISU DAN PERMASALAHAN PEMBANGUNAN PERIKANAN BUDI DAYA NASIONAL}

Salah satu isu strategis yang dihadapi dalam pembangunan nasional di Indonesia adalah menjadikan sub sektor perikanan budi daya sebagai penggerak perekonomian nasional yang berkelanjutan. Kebijakan untuk mendorong sub sektor perikanan budi daya menjadi sektor 
unggulan dalam pembangunan perikanan nasonal sangat tepat karena didukung dengan dua komponen utama yang mendukung pengembangan sektor ini, yaitu komponen biofisik dan komponen sosial ekonomi. Menurut Rizal (2013), komponen biofisik adalah modal potensi sumber daya lahan perikanan budi daya yang sangat luas dan keanekaragaman jenis komoditas ikan yang masing masing memiliki nilai penting baik dari sisi pasar domestik maupun pasar internasional. Secara sosial ekonomi, 60\% penduduk Indonesia hidup di wilayah pesisir dan secara ekonomi industri perikanan telah mampu menyerap kurang lebih 16.000 orang tenaga kerja secara langsung. Menurut Rizal, Iskandar, Heti, \& Lantun (2018), ada tiga syarat utama yang harus dipenuhi agar sektor perikanan dapat menjadi motor penggerak utama perekonomian nasional, yaitu (i) sektor perikanan harus memberikan dampak ekonomi yang signifikan secara makro; (ii) sektor perikanan dapat memberikan keuntungan dan kesejahteraan yang signifikan dan merata terhadap semua pelaku usaha di dalamnya dibandingkan dengan sektor-sektor lain; serta (iii) pembangunan perikanan yang dilaksanakan harus berkesinambungan dan holistik, serta terintegrasi dari hulu ke hilir tidak hanya secara ekonomi tetapi juga secara ekologi.

Permasalahan dan tantangan yang dihadapi dalam pembangunan perikanan budi daya di
Indonesia sangat kompleks dan bersifat multi dimensi. Penelitian ini telah melakukan Focus Group Discussion (FGD) melibatkan multi stakeholders untuk memetakan permasalahan dan tantangan pembangunan perikanan budi daya nasional. Urgensi permasalahan dapat ditinjau berdasarkan tingkat kepentingan dan konsensus semua stakeholders. Semakin penting suatu permasalahan atau tantangan menurut stakeholders maka penyelesaian permasalahan tersebut semakin menjadi prioritas. Kesepakatan dalam FGD adalah tingkat kepentingan diklasifikasikan menjadi tiga, yaitu cukup penting, penting, dan sangat penting. Permasalahan pembangunan perikanan budi daya nasional berdasarkan tipologi ekosistem perikanan diklasifikasikan menjadi tiga, yaitu air tawar, air payau, dan air laut dengan mempertimbangkan tiga aspek pembangunan berkelanjutan, yaitu lingkungan, ekonomi, dan sosial.

Tabel 1 menjelaskan bahwa ada tujuh belas potensi permasalahan yang dihadapi dalam pembangunan perikanan budi daya nasional yang terdiri atas enam potensi permasalahan pada dimensi lingkungan, tujuh potensi permasalahan pada dimensi ekonomi, dan empat potensi permasalahan pada dimensi sosial. Pada dimensi ekonomi yang menjadi permasalahan di sisi produksi adalah terkait tingginya biaya produksi. Ini dipengaruhi oleh mahalnya harga input

Tabel 1. Permasalahan Pembangunan Perikanan Budi Daya di Indonesia.

\begin{tabular}{|c|c|c|c|c|c|}
\hline \multirow{2}{*}{ Dimensi } & \multirow{2}{*}{\multicolumn{2}{|c|}{ Uraian Permasalahan }} & \multicolumn{3}{|c|}{ Tipologi Usaha } \\
\hline & & & Air Tawar & Air Payau & Air Laut \\
\hline \multirow[t]{6}{*}{ Lingkungan } & 1. & Penurunan daya dukung lingkungan dan perairan & +++ & +++ & +++ \\
\hline & 2. & Ketersedian instalasi pengolah limbah & ++ & +++ & ++ \\
\hline & 3. & Penyakit & +++ & +++ & +++ \\
\hline & 4 & Penerapan Cara Budi Daya Ikan yang Baik (CBIB) & +++ & +++ & +++ \\
\hline & 5. & Pengaturan alokasi ruang, zonasi, dan irigasi & ++ & +++ & +++ \\
\hline & 6. & Infrastruktur pendukung yang tidak memadai & +++ & +++ & ++ \\
\hline \multirow[t]{7}{*}{ Ekonomi } & 1. & Biaya produksi tinggi & +++ & ++ & ++ \\
\hline & 2. & Akses Modal & +++ & ++ & ++ \\
\hline & 3. & Akses Pasar & +++ & ++ & +++ \\
\hline & 4. & Keuntungan tidak merata & +++ & +++ & +++ \\
\hline & 5. & Produktivitas masih rendah & ++ & ++ & +++ \\
\hline & 6. & Kemudahan investasi & +++ & +++ & +++ \\
\hline & 7. & Keterbatasan anggaran pemerintah & ++ & ++ & ++ \\
\hline \multirow[t]{4}{*}{ Sosial } & 1. & Kualitas sumber daya manusia & +++ & +++ & +++ \\
\hline & 2. & Sertifikasi tenaga kerja & + & ++ & ++ \\
\hline & 3. & Keamanan lingkungan & ++ & +++ & +++ \\
\hline & 4. & Asimetrik regulasi dan kebijakan & +++ & +++ & +++ \\
\hline
\end{tabular}

Keterangan : + (cukup penting) ; ++ (penting) ; +++ (sangat penting)

Sumber: Data primer diolah, 2019 
produksi, khususnya pakan yang menjadi beban biaya terbesar dalam usaha perikanan budi daya. Hal ini sesuai dengan penelitian yang dilakukan oleh Juarno et al. (2011) dan Imamah, Hartoyo, Syaukat, \& Utami (2013) yang menyatakan bahwa komponen biaya pakan berkontribusi terhadap $40 \%-60 \%$ biaya produksi usaha perikanan budi daya di Indonesia. Menurut Juarno et al. (2011), pakan merupakan penyumbang biaya produksi pada usaha perikanan budi daya yang menggunakan teknologi intensif, sedangkan upah tenaga kerja merupakan penyumbang terbesar pada usaha budi daya yang menggunakan teknologi semi intensif dan ekstensif. Hasil penelitian yang dilakukan Juarno et al. (2011) sedikit berbeda dengan hasil dalam FGD yang menyimpulkan bahwa pengaruh harga pakan terhadap tingginya biaya produksi lebih dirasakan pengaruhnya oleh pembudi daya ikan air tawar di semua skala usaha dan semua sistem teknologi. Hal ini dipengaruhi oleh harga komoditas perikanan budi daya air tawar yang relatif lebih rendah sehingga margin keuntungan yang diperoleh pembudi daya sangat kecil. Oleh karena itu, kebijakan dan program pemerintah yang mendorong tersedianya pakan yang bermutu dan murah perlu dilakukan secara masif. Program pakan mandiri yang sudah dilaksanakan pemerintah perlu didukung dengan penyediaan bahan baku yang murah, karena ini menjadi salah satu faktor yang mengakibatkan mahalnya harga pakan ikan dan sangat fluktuatif terhadap perubahan kurs.

Pemasalahan dan tantangan lain yang perlu menjadi perhatian dalam pembangunan perikanan budi daya nasional ke depan adalah terkait pemerataan keuntungan dan kemudahan investasi. Permasalahan ini menjadi prioritas yang harus dapat diselesaikan di semua tipologi usaha perikanan budi daya. Terjadinya pembagian keuntungan yang tidak merata dalam sistem bisnis perikanan budi daya di Indonesia sama dengan hasil studi USAID (2006) di Bangladesh yang menemukan bahwa pedagang dan eksportir menerima bagian keuntungan lebih besar dibandingkan pembudidaya ikan. Tajerin \& Noor (2005) dalam penelitiannya menyatakan bahwa semua pembudi daya ikan adalah penerima harga (price taker) baik dalam pasar input produksi maupun pasar output produksi. Perbaikan sistem rantai pasok dan penguatan kelembagaan pembudi daya ikan dapat menjabat salah satu kebijakan yang perlu dilakukan untuk meminimalisasi terjadinya keuntungan yang tidak merata. Pemanfaatan teknologi 4.0 bisa menjadi solusi jangka panjang untuk mengefisienkan rantai pasok usaha perikanan budi daya dan meningkatkan keuntungan serta posisi produsen dalam sistem pasar. Pada dimensi sosial, kualitas sumber daya manusia dan asimetris kebijakan menjadi permasalahan yang diperkirakan akan sangat berpengaruh dalam kinerja perikanan budi daya. Hasil penelitian Juarno et al. (2011) memperkuat rumusan permasalahan tentang pentingnya kualitas sumber daya manusia dalam kinerja perikanan budi daya, bahwa tingkat pendidikan pembudi daya berkorelasi positif terhadap peningkatan TFP untuk kegiatan usaha budi daya udang. Hal ini diperkuat dengan hasil penelitian Koeshendrajana, Suryawati, Saptanto, \& Nasution (2004) yang menyatakan bahwa pendidikan atau kualitas SDM menjadi salah satu indikator penting yang dipertimbangkan dalam pengelolaan perikanan budi daya berkelanjutan. Menurut KKP (2005), konfigurasi pembudi daya berdasarkan tingkat pendidikan, yaitu $3,2 \%$ tidak tamat sekolah; $43,6 \%$ tamat sekolah dasar; dan hanya $7,7 \%$ lulusan perguruan tinggi. Program yang terkait dengan pelatihan-pelatihan teknis dan manajerial bagi pembudi daya ikan perlu diperkuat untuk meningkatkan kapasitas SDM mengingat di masa datang persaingan akan semakin kuat.

Pada dimensi lingkungan, permasalahan utama pembangunan perikanan budi daya di Indonesia, antara lain: penurunan daya dukung lingkungan dan perairan, penyakit, penerapan $\mathrm{CBIB}$, dan ketersediaan infrastruktur pendukung yang tidak memadai. Penyakit merupakan salah satu permasalahan yang berdampak secara langsung terhadap kinerja pembangunan perikanan budi daya baik ditinjau dari efisiensi maupun produktivitas. Dampak penyakit terhadap penurunan produktivitas dapat dilihat dari penurunan produksi rumput laut di Indonesia pada tahun 2018 sebesar 10\% (KKP, 2019). Pengaruh penyakit terhadap aspek ekonomi dibuktikan dalam penelitian Valderrama \& Engle (2004) yang menunjukkan bahwa penyakit virus Taura Syndrome Virus (TSV) dan White Spot Syndrome Virus (WSSV) menurunkan keuntungan usaha budi daya ikan sebesar $84 \%$ dibandingkan dengan usaha budi daya udang yang tidak terkena penyakit. Kondisi ini diperkuat dengan hasil penelitian Juarno et al. (2011) yang menunjukkan bahwa $70 \%$ responden menyatakan terhindarnya penyakit adalah faktor utama yang paling menentukan keberhasilan budi daya udang dan berimplikasi pada produktivitas usaha. 


\section{KINERJA PEMBANGUNAN PERIKANAN BUDI DAYA NASIONAL}

Efisiensi dan produktivitas merupakan salah satu indikator dalam pengukuran suatu kinerja pembangunan baik yang bersifat regional maupun sektoral. Hasil analisis dengan menggunakan DEA dan alat analisis banxia frontier pada tujuh belas provinsi yang menjadi DMU menunjukkan bahwa kinerja perikanan budi daya berdasarkan tipologi ekosistem yang digunakan sebagai berikut.

1. Efisiensi dan produktivitas perikanan budi daya air laut

Hasil pengukuran kinerja perikanan budi daya laut tahun 2013 - 2017 pada tujuh belas provinsi di Indonesia dengan menggunakan metode DEA dapat dilihat pada Gambar 1. Hasil analisis dengan DEA menunjukkan bahwa nilai efisiensi rata-rata pembangunan perikanan budi daya pada periode 2013 - 2017 di tujuh belas DMU berturut - turut adalah 48\%, 52\%, 37\%, 39\%, dan 38\%. Hal ini menunjukkan bahwa kinerja pembangunan perikanan budi daya laut di Indonesia belum efisien dilakukan oleh semua DMU. Pada tahun 2013, ada empat DMU yang memiliki kinerja efisien, yaitu Provinsi Gorontalo, Jawa Tengah, Kepulauan Bangka Belitung, dan Sumatra Utara. Pada tahun 2014, ada lima DMU yang memiliki kinerja efisien, yaitu Provinsi Jawa Barat, Jawa Tengah, Kalimantan Timur, Kepulauan Bangka Belitung, dan Sumatra Utara. Pada tahun 2015 dan 2017, ada tiga DMU yang memiliki kinerja efisien, yaitu Provinsi Jawa Tengah, Kalimantan Timur, dan Kepulauan Bangka Belitung, sedangkan efisiensi kinerja yang terjadi di lima DMU pada tahun 2016, yaitu Provinsi Bali, Jawa Tengah, Kalimantan Timur, Kepulauan Bangka Belitung, dan Sumatra Utara. Gambar 1 menunjukkan bahwa Provinsi Jawa Tengah dan Kepulauan Bangka Belitung adalah DMU yang memiliki kinerja paling efisien untuk pembangunan perikanan budi daya laut selama lima tahun di Indonesia. Hal ini ditunjukkan dengan nilai efisiensi sebesar $100 \%$ setiap tahunnya pada periode tahun 2013-2017. Nilai efisiensi $100 \%$ yang mengindikasikan bahwa alokasi input yang digunakan adalah luas lahan dan jumlah pembudi daya sudah sesuai dengan output yang dihasilkan, yaitu volume produksi dan pendapatan sehingga sudah tidak diperlukan penambahan input dan output lagi. Namun sebaliknya pada Gambar 2 terlihat bahwa Provinsi Jawa Timur menjadi DMU yang memiliki nilai efisiensi paling kecil selama lima tahun, yaitu $13 \%, 12 \%, 6 \%, 2 \%$, dan $3 \%$. Rendahnya nilai efisiensi ini menunjukkan dua sisi yang berbeda, yaitu di satu sisi menunjukkan kinerja yang dilakukan tidak efisien, namun di sisi lain menunjukkan potensi peningkatan efisiensi melalui rekalkulasi penggunaan input dan output. Sebagai contoh, Jawa Timur pada tahun 2017 menunjukkan tingkat efisiensi sangat rendah dengan nilai efisiensi $2 \%$. Mengacu pada Provinsi Kalimantan Timur sebagai peer reference unit, maka efisensi kinerja perikanan budi daya laut di Provinsi Jawa Timur mempunyai potensi untuk ditingkatkan melalui peningkatan volume $4.164 \%$, peningkatan pendapatan $5.061 \%$, dan pengurangan jumlah pembudi daya $65 \%$. Secara keseluruhan, berdasarkan perhitungan perbandingan total input dan total output, maka total potensi peningkatan efisiensi pembangunan perikanan budi daya laut di tujuh belas DMU dapat dilakukan melalui pengurangan total penggunaan luas lahan sebesar $2 \%$ serta peningkatan total volume produksi dan total pendapatan sebesar $17 \%$ dan $82 \%$.

Gambar 1 menunjukkan bahwa 76\% lokasi DMU cenderung memiliki nilai efisiensi berfluktuasi selama periode 5 tahun. Hal ini disebabkan karena produksi pada sektor perikanan budi daya laut tidak hanya ditentukan oleh input yang terkendali, namun juga dipengaruhi oleh faktor lain, seperti kondisi perairan laut, cuaca, akses pasar, harga, dan penyakit. Hal ini sesuai dengan hasil penelitian yang dilakukan oleh Rahman, Nielsen, Khan, \& Asmild (2019), yang menyatakan bahwa efisiensi suatu usaha perikanan budi daya akan sangat dipengaruhi oleh kondisi geografis dan lingkungan, sehingga variasi spasial akan berimplikasi pada perbedaan karakteristik lingkungan. Apabila perbedaan ini tidak diperhitungkan, maka dapat menyebabkan pilihan teknologi dan jenis komoditas menjadi tidak sesuai, sehingga akan menyebabkan penggunaan sumber daya yang tidak efisien. Pemilihan komoditas yang sesuai dengan kondisi lingkungan juga menjadi hal yang perlu dipertimbangkan untuk mencapai efisiensi usaha yang optimal, karena semua spesies yang dihasilkan dalam usaha perikanan budi daya memiliki kebutuhan biologis yang spesifik, seperti suhu, kualitas air, dan pakan untuk mencapai potensi pertumbuhan optimalnya, sedangkan sebagian besar wilayah tidak menawarkan lingkungan produksi yang homogen (Sharma \& Leung, 2000; Manjarrez, Soto, \& Brummett, 2017). 


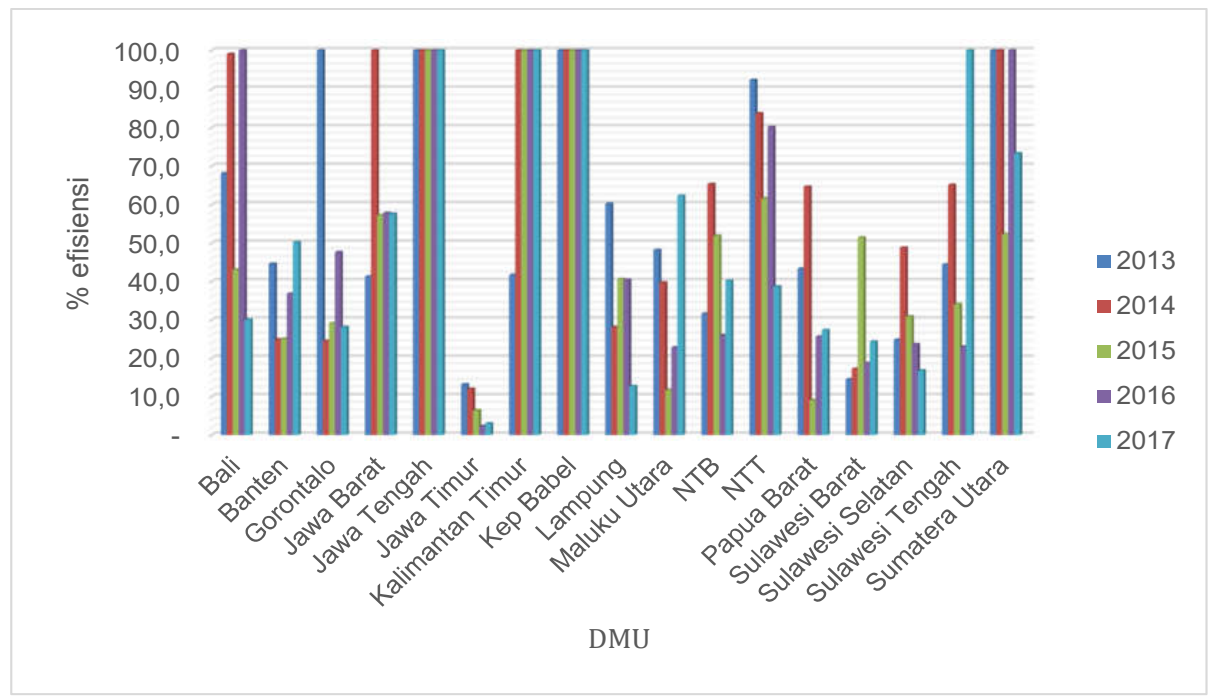

Gambar 1. Tingkat Efisiensi Pembangunan Perikanan Budi Daya Laut di Indonesia Tahun 2013 - 2017. Sumber: Data sekunder diolah, 2019

Hasil analisis indeks malmquist dengan metode DEA menggunakan asumsi maksimalisasi output menunjukkan bahwa terjadi peningkatan produktivitas rata - rata sebesar $8 \%$ di tujuh belas DMU pada periode 2013 - 2017. Hal ini ditunjukkan dengan nilai rata - rata geometrik indeks malmquist 1,08. Hasil perhitungan DEA menunjukkan bahwa nilai rata - rata indeks malmquist selama lima tahun untuk tujuh belas DMU di Indonesia adalah di antara 0,73 2,05. Peningkatan produktivitas selama tahun 2013 - 2017 di lokasi DMU berdasarkan nilai indeks malmquist, yaitu Banten $(1,27)$, Jawa Timur $(1,08)$, Kalimantan Timur $(2,05)$, Kepulauan Bangka Belitung $(1,15)$, Maluku Utara $(1,39)$, Nusa Tenggara Barat $(1,27)$, Sulawesi Barat $(1,32)$, Sulawesi Selatan (101), dan Sulawesi Tengah $(1,51)$ yang ditunjukkan dengan nilai indeks malmquist $>1$. Tabel 2 menunjukkan bahwa peningkatan produktivitas rata - rata perikanan budi daya laut tertinggi di tujuh belas DMU terjadi pada periode 2016 - 2017 sebesar $37 \%$, yang ditunjukkan dengan nilai indeks malmquist sebesar 1,37 (> 1). Sebaliknya, penurunan

Tabel 2. Nilai Indeks Malmquist Kinerja Perikanan Budi Daya Laut di Indonesia Tahun 2013 - 2017.

\begin{tabular}{|c|c|c|c|c|c|c|}
\hline \multirow{2}{*}{ No } & \multirow{2}{*}{ DMU } & \multicolumn{4}{|c|}{ Indek Malmquist } & \multirow{2}{*}{$\begin{array}{l}\text { Rata-rata } \\
2013-2017\end{array}$} \\
\hline & & $2013-2014$ & 2014-2015 & $2015-2016$ & 2016-2017 & \\
\hline 1 & Bali & 1,72 & 0,74 & 0,94 & 0,56 & 0,90 \\
\hline 2 & Banten & 0,60 & 1,82 & 1,15 & 2,06 & 1,27 \\
\hline 3 & Gorontalo & 0,22 & 2,10 & 0,54 & 1,14 & 0,73 \\
\hline 4 & Jawa Barat & 6,24 & 0,64 & 0,09 & 1,67 & 0,88 \\
\hline 5 & Jawa Tengah & 2,14 & 1,62 & 0,26 & 0,98 & 0,97 \\
\hline 6 & Jawa Timur & 0,97 & 1,09 & 1,04 & 1,25 & 1,08 \\
\hline 7 & Kalimantan Timur & 2,15 & 2,06 & 4,53 & 0,88 & 2,05 \\
\hline 8 & Kep. Babel & 2,67 & 1,08 & 0,24 & 2,56 & 1,15 \\
\hline 9 & Lampung & 1,00 & 0,94 & 0,72 & 0,81 & 0,86 \\
\hline 10 & Maluku Utara & 0,69 & 0,50 & 2,62 & 4,18 & 1,39 \\
\hline 11 & NTB & 1,41 & 1,49 & 0,82 & 1,52 & 1,27 \\
\hline 12 & NTT & 0,95 & 1,25 & 0,82 & 0,60 & 0,87 \\
\hline 13 & Papua Barat & 1,37 & 0,25 & 1,76 & 1,48 & 0,97 \\
\hline 14 & Sulawesi Barat & 1,02 & 5,05 & 0,35 & 1,66 & 1,32 \\
\hline 15 & Sulawesi Selatan & 1,22 & 1,14 & 0,99 & 0,76 & 1,01 \\
\hline 16 & Sulawesi Tengah & 1,00 & 0,98 & 1,16 & 4,55 & 1,51 \\
\hline 17 & Sumatera Utara & 1,00 & 1,03 & 0,23 & 1,25 & 0,74 \\
\hline & Rerata & 1,21 & 1,14 & 0,71 & 1,37 & 1,08 \\
\hline
\end{tabular}

Sumber: Data sekunder diolah, 2019 
produktivitas sebesar $29 \%$ terjadi pada periode 2015 - 2016 yang ditunjukkan dengan nilai rata-rata indeks malmquist $0,71(<1)$. Penurunan produktivitas terjadi di $60 \%$ DMU yang diakibatkan karena terjadinya inefisiensi produksi dan perubahan teknologi yang ditunjukkan dengan nilai catch up dan frontier shift yang lebih kecil dari $1(<1)$.

2. Efisiensi dan produktivitas perikanan budi daya air payau

Hasil analisis dengan DEA menunjukkan bahwa nilai efisiensi rata-rata pembangunan perikanan budi daya pada tujuh belas DMU setiap tahun adalah $53,5 \%, 50 \%, 54 \%, 47 \%$, dan $9 \%$ (Gambar 2). Secara akumulatif nilai rata rata efisiensi kinerja pembangunan perikanan budi daya yang sudah dilaksanakan selama periode 2013-2017 adalah 35,7\%. Hal ini menunjukkan bahwa kinerja pembangunan perikanan budi daya payau di Indonesia belum efisien dilakukan di semua DMU. Faktor - faktor yang mengakibatkan belum efisiensinya kinerja pembangunan perikanan budi daya air payau adalah terjadinya inefisiensi penggunaan input lahan dan tenaga, serta belum optimalnya pencapaian output produksi serta pendapatan, sehingga perlu dilakukan pengurangan penggunaan input luas lahan dan tenaga kerja sebesar $0,3 \%$ dan $1 \%$ serta peningkatan volume produksi dan pendapatan sebesar $40 \%$ dan 59\%. Jumlah DMU yang telah melakukan kinerja secara efisien adalah delapan provinsi, yaitu Provinsi Bali, Banten, Maluku Utara, Kepulauan Bangka Belitung, Nusa Tenggara Barat, Maluku Utara, Papua Barat, dan Sulawesi Tengah.
Gambar 2 menunjukkan bahwa Provinsi Bali adalah DMU yang secara konsisten memiliki kinerja paling efisien selama 5 tahun, sedangkan yang lain cenderung lebih fluktuatif, ditunjukkan dengan nilai efisiensi sebesar $100 \%$ setiap tahun. Hal ini berarti penggunaan input telah menghasilkan output yang optimal. Informasi yang diperoleh dari Gambar 2 bahwa ada sepuluh DMU yang memiliki kinerja pembangunan perikanan budi daya air payau yang belum efisien (nilai efisiensi $<100 \%$ ) selama lima tahun, yaitu Provinsi Gorontalo, Jawa Tengah, Jawa Barat, Jawa Timur, Kalimantan Timur, Lampung, dan Sumatra Utara. DMU yang memiliki nilai efisiensi paling kecil selama 5 tahun adalah Provinsi Kalimantan Timur yang ditunjukkan dengan nilai efisiensi $6 \%, 19, \%$, $16 \%, 5 \%$, dan $1 \%$. Hasil penelitian menunjukkan bahwa faktor yang mengakibatkan kinerja Provinsi Kalimantan Timur tidak efisien adalah terjadinya inefisensi alokasi penggunaan output dan belum optimalnya output yang dihasilkan.

Di sisi lain, hasil analisis DEA menunjukkan bahwa 95\% lokasi DMU cenderung memiliki skor efisiensi yang fluktuatif selama periode lima tahun. Jumlah ini lebih besar apabila dibandingkan dengan yang terjadi di usaha perikanan budi daya laut. Hal ini terjadi karena pada sektor perikanan budi daya air payau tingkat faktor - faktor yang mempengaruhi tingkat efisiensi lebih kompleks. Efisiensi usaha tidak hanya ditentukan oleh input yang terkendali namun juga dipengaruhi oleh faktor lain, seperti kondisi lingkungan tambak, ketersediaan sumber air, cuaca, dan penyakit. Hal ini sesuai dengan studi Tajerin (2007) yang menyatakan bahwa keluaran (output) yang dicapai merupakan resultante dari kinerja multi faktor,

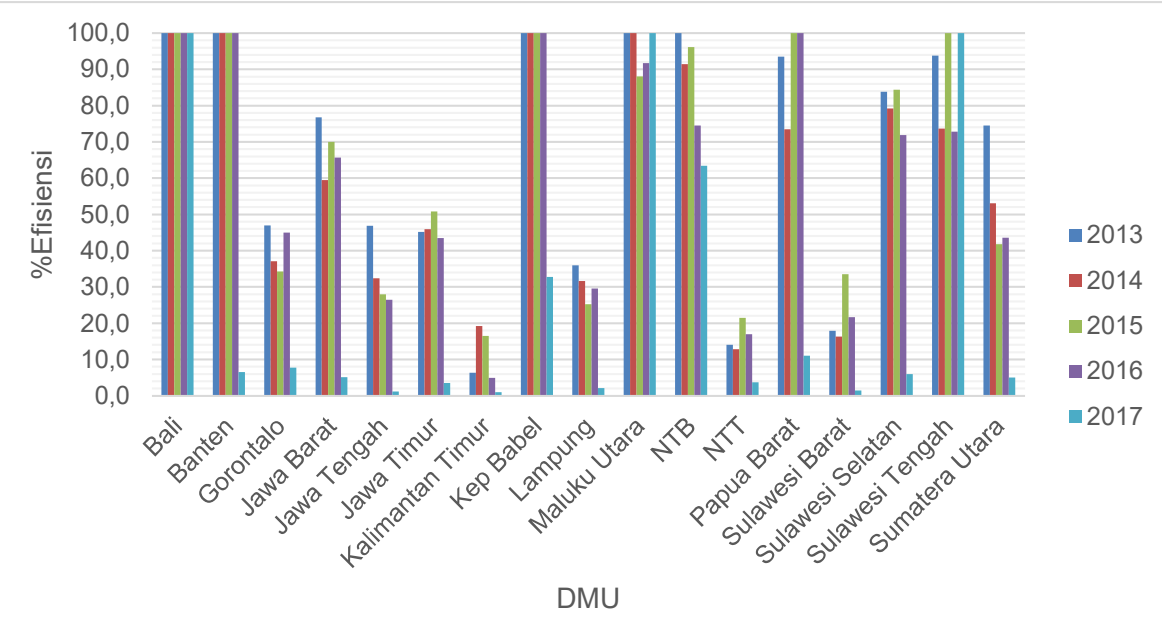

Gambar 2. Tingkat Efisiensi Pembangunan Perikanan Budi Daya Payau di Indonesia Tahun 2013 - 2017. Sumber: Data sekunder diolah, 2019 
yaitu faktor eksternal dan faktor internal, serta didukung dengan hasil penelitian yang dilakukan oleh Rahman et al. (2019) yang menyatakan bahwa efisiensi suatu usaha perikanan budi daya akan sangat dipengaruhi oleh kondisi geografis dan lingkungan di setiap wilayah, sehingga variasi spasial akan sangat berimplikasi pada pencapaian kinerja karena menyebabkan pilihan teknologi dan jenis komoditas menjadi tidak efisien. Pemilihan komoditas yang sesuai dengan kondisi lingkungan juga menjadi hal yang perlu dipertimbangkan untuk mencapai efisiensi usaha yang optimal karena setiap komoditas perikanan budi daya memiliki kebutuhan biologis (suhu, kualitas air, dan pakan) yang spesifik untuk mencapai potensi pertumbuhan optimalnya, sedangkan sebagian besar wilayah tidak menawarkan lingkungan produksi yang homogen (Sharma \& Leung, 2000; Manjarrez et al., 2017).

Tabel 3 menunjukkan hasil perhitungan kinerja produktivitas pada periode 2013 - 2017 berdasarkan nilai indeks malmquist. Hasil penelitian menunjukkan bahwa terjadi peningkatan produktivitas rata-rata perikanan budi daya air payau pada periode 2013 - 2017 di tujuh belas DMU sebesar $13 \%$, dengan nilai rata - rata indeks malmquist 1,13. Hasil perhitungan dengan DEA Malmquist menunjukan bahwa nilai rata rata indeks malmquist selama lima tahun untuk tujuh belas DMU di Indonesia antara 0,8 - 2 .
Hasil estimasi mengidentifikasi ada sebelas DMU yang mengalami peningkatan produktivitas yang ditunjukkan dengan nilai indeks malmquist $>1$, yaitu Bali $(1,97)$, Gorontalo $(1,16)$, Jawa Timur $(1,03)$, Kalimantan Timur $(1,04)$, Kepulauan Bangka Belitung (1,16), Maluku Utara $(1,28)$, Nusa Tenggara Barat $(1,73)$, Nusa Tenggara Timur $(1,16)$, Sulawesi Barat $(1,05)$, Sulawesi Tengah $(2,0)$, dan Sumatra Utara $(1,01)$. Peningkatan produktivitas rata - rata perikanan budi daya air payau terbesar di tujuh belas DMU terjadi pada periode 2016-2017, yaitu sebesar 43\% dengan nilai indeks malmquist sebesar 1,43. Peningkatan produktivitas di sebagian besar DMU diakibatkan karena terjadinya perubahan penggunaan teknologi (frontier shift) rata-rata sebesar $794 \%$ khususnya untuk usaha budi daya udang dari ekstensif menjadi intensif atau supra intensif dan adanya pembukaan tambak baru menggunakan teknologi intensif berbasis kluster kawasan, namun peningkatan teknologi tersebut tidak diikuti dengan peningkatan efisiensi teknis. Hal ini ditunjukkan dengan terjadinya penurunan rata-rata efisiensi teknis usaha budi daya air payau sebesar $74 \%$ yang ditunjukkan dengan nilai catch up $0,24(<1)$.

Dari Tabel 3 juga dapat dilihat terjadi penurunan produktivitas sebesar $3 \%$ pada periode 2014 - 2015 yang ditunjukkan dengan nilai rata-rata indeks malmquist 0,97 $(<1)$. Penurunan

Tabel 3. Nilai indeks Malmquist Kinerja Perikanan Budi Daya Air Payau di Indonesia Tahun 2013 - 2017.

\begin{tabular}{|c|c|c|c|c|c|c|}
\hline \multirow{2}{*}{ No } & \multirow{2}{*}{ DMU } & \multicolumn{4}{|c|}{ Indek Malmquist } & \multirow{2}{*}{$\begin{array}{c}\text { Rata-rata } \\
2013-2017\end{array}$} \\
\hline & & $2013-2014$ & 2014-2015 & 2015-2016 & 2016-2017 & \\
\hline 1 & Bali & 1,34 & 0,94 & 1,44 & 8,23 & 1,97 \\
\hline 2 & Banten & 0,93 & 0,94 & 1,10 & 0,68 & 0,90 \\
\hline 3 & Gorontalo & 0,73 & 0,88 & 1,52 & 1,83 & 1,16 \\
\hline 4 & Jawa Barat & 0,78 & 1,15 & 1,19 & 0,85 & 0,98 \\
\hline 5 & Jawa Tengah & 0,95 & 0,84 & 1,44 & 0,35 & 0,80 \\
\hline 6 & Jawa Timur & 1,08 & 1,09 & 1,08 & 0,89 & 1,03 \\
\hline 7 & Kalimantan Timur & 2,73 & 0,80 & 0,37 & 1,46 & 1,04 \\
\hline 8 & Kep. Babel & 1,06 & 1,02 & 1,12 & 1,50 & 1,16 \\
\hline 9 & Lampung & 0,86 & 0,76 & 1,29 & 0,75 & 0,89 \\
\hline 10 & Maluku Utara & 1,01 & 1,01 & 0,47 & 5,53 & 1,28 \\
\hline 11 & NTB & 1,11 & 0,97 & 1,25 & 6,73 & 1,73 \\
\hline 12 & NTT & 1,08 & 1,59 & 0,96 & 1,08 & 1,16 \\
\hline 13 & Papua Barat & 1,94 & 0,30 & 2,15 & 0,42 & 0,85 \\
\hline 14 & Sulawesi Barat & 1,02 & 2,24 & 0,82 & 0,66 & 1,05 \\
\hline 15 & Sulawesi Selatan & 1,08 & 1,05 & 1,20 & 0,64 & 0,97 \\
\hline 16 & Sulawesi Tengah & 0,92 & 1,31 & 1,08 & 12,40 & 2,00 \\
\hline 17 & Sumatra Utara & 0,83 & 0,76 & 1,51 & 1,08 & 1,01 \\
\hline & Rerata & 1,08 & 0,97 & 1,09 & 1,43 & 1,13 \\
\hline
\end{tabular}

Sumber: Data sekunder diolah, 2019 
produktivitas terjadi diakibatkan oleh adanya wabah virus EMS dan bercak putih yang menyerang usaha budi daya udang secara global termasuk di Indonesia, sehingga implikasinya pembudi daya udang melakukan usaha budi daya dengan teknologi yang lebih rendah dan pada tebar yang rendah atau merubah jenis komoditas usahanya menjadi bandeng, nila salin atau dengan teknologi polyculture. Penurunan penggunaan teknologi yang terjadi sebesar $23 \%$ ditunjukkan dengan nilai frontier shift 0,77. Hal ini mengakibatkan terjadinya efisiensi usaha budi daya air payau rata-rata meningkat sebesar $24 \%$ yang ditunjukkan dengan nilai catch up 1,24 . Perubahan teknologi berimplikasi positif pada peningkatan total faktor produktivitas usaha perikanan budi daya air payau namun berimplikasi negatif terhadap efisiensi usahanya. Pengaruh positif intensifikasi pada total faktor produktifitas usaha perikanan budi daya air payau sesuai dengan hasil penelitian yang dilakukan Juarno et al. (2011) pada usaha budi daya udang, sedangkan hasil yang menyatakan bahwa intensifikasi mengakibatkan penurunan efisiensi usaha berbeda dengan hasil penelitian yang dilakukan oleh Aisya, Koeshendrajana, \& lqbal (2005) yang menyatakan bahwa usaha budi daya udang intensif paling efisien dalam penggunaan biaya domestik.

3. Efisiensi dan produktivitas perikanan budi daya air tawar

Hasil analisis nilai efisiensi rata-rata pembangunan perikanan budi daya air tawar pada periode 2013-2017 berturut-turut adalah $61 \%$, 55\%, 50\%, 57\%, dan 29\% (Gambar 3).
Secara akumulatif nilai rata rata efisiensi kinerja pembangunan perikanan budi daya air tawar yang sudah dilaksanakan selama periode 2013-2017 adalah $49 \%$. Hal ini menunjukkan bahwa kegiatan pembangunan perikanan budi daya air tawar belum efisien dilakukan di semua DMU. Faktor - faktor yang mengakibatkan belum efisiennya kinerja pembangunan perikanan budi daya air tawar adalah terjadinya inefisiensi penggunaan input lahan dan tenaga, dan belum optimalnya pencapaian output produksi serta pendapatan, di sisi lain, hasil analisis DEA menunjukkan bahwa 95\% lokasi DMU cenderung memiliki nilai efisiensi yang fluktuatif selama periode lima tahun. Jumlah ini sama dengan perikanan budi daya air payau namun lebih besar apabila dibandingkan dengan yang terjadi di usaha perikanan budi daya laut, perlu dilakukan pengurangan penggunaan input luas lahan dan tenaga kerja sebesar $1,8 \%$ dan $3 \%$, serta peningkatan volume produksi dan pendapatan sebesar $25 \%$ dan $70 \%$.

Gambar 3 menunjukkan bahwa Provinsi Kepulauan Bangka Belitung adalah DMU yang secara konsisten memiliki kinerja paling efisien selama lima tahun, sedangkan yang lain cenderung berfluktuatif, ditunjukkan dengan nilai efisiensi sebesar $100 \%$ untuk setiap tahun, yang berarti bahwa penggunaan input telah menghasilkan output yang optimal, sebaliknya, ada tujuh DMU yang memiliki kinerja pembangunan perikanan budi daya air payau yang belum efisien (nilai efisiensi $<100 \%$ ) selama 5 tahun, yaitu Provinsi Jawa Barat, Jawa Tengah, Jawa Timur, Lampung, NTT, Sulawesi Barat, dan Sumatra Utara. Hasil penelitian menunjukkan bahwa pada tahun 2017, Provinsi Jawa Barat, Jawa Tengah, dan

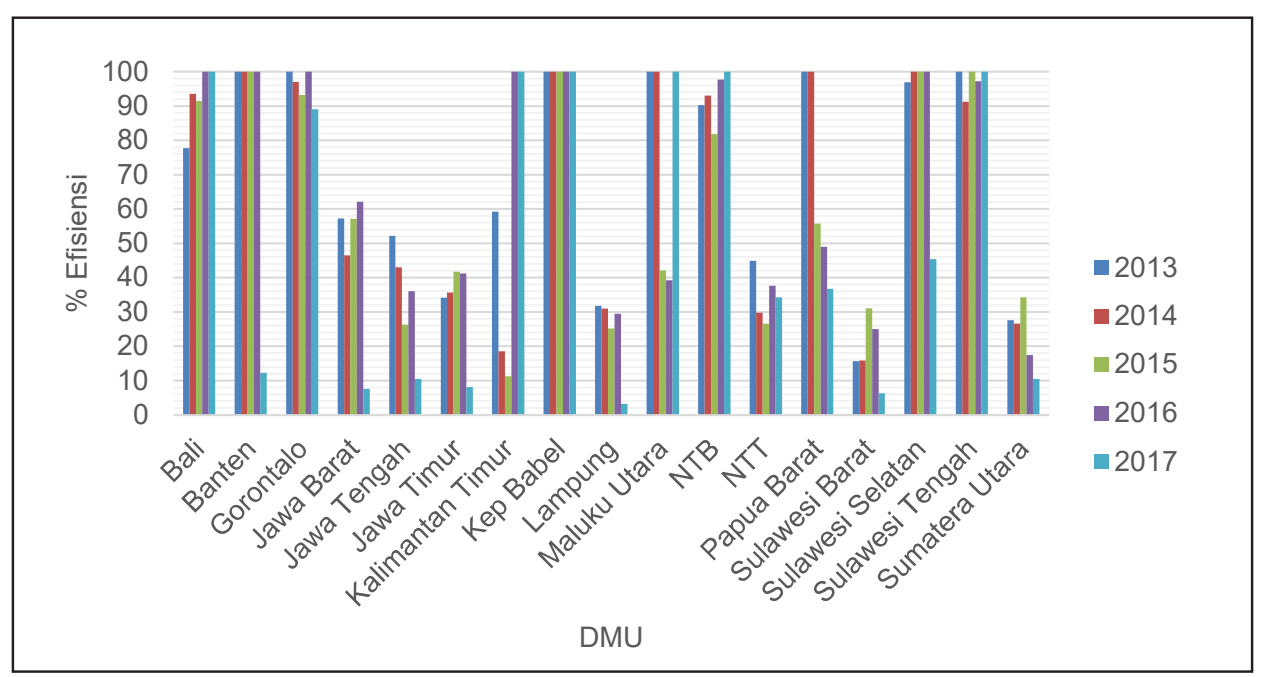

Gambar 3. Tingkat Efisiensi Pembangunan Perikanan Budi Daya Air Tawar di Indonesia Tahun 2013 - 2017. Sumber: Data sekunder diolah, 2019 
Jawa Timur memiliki nilai efisiensi yang sangat rendah, yaitu $8-10,5 \%$. Hal ini menjadi temuan menarik dalam penelitian ini, mengingat ketiga DMU tersebut mempunyai keuntungan komparatif dibandingkan lokasi lainnya karena lokasinya dekat dengan pusat penyediaan input produksi dan pasar. Hasil analisis menunjukkan bahwa faktor yang mengakibatkan inefisiensi usaha di Provinsi Jawa Barat adalah output yang tidak optimal, sehingga untuk meningkatkan efisiensi usaha perlu dilakukan peningkatan volume produksi dan pendapatan pembudi daya masing masing sebesar $2.540 \%$ dan $1.200 \%$, sedangkan faktor input tetap. Inefisiensi kinerja perikanan budi daya air tawar di Provinsi Jawa Timur dan Jawa Tengah, disebabkan oleh penggunaan input yang tidak efisien dan hasil output yang tidak optimal. Potensi peningkatan efisiensi di Provinsi Jawa Timur dapat dilakukan melalui pengurangan tenaga kerja sebanyak $32 \%$ serta peningkatan volume produksi dan penerimaan pembudi daya sebesar $1.120 \%$ dan $2.100 \%$, sedangkan peningkatan efisiensi di Provinsi Jawa Tengah dapat dilakukan melalui pengurangan tenaga kerja sebanyak $85 \%$ serta peningkatan volume produsi dan penerimaan pembudi daya sebesar $850 \%$.

Tabel 4 menunjukkan hasil perhitungan total faktor produktivitas yang ditunjukkan dengan nilai indeks malmquist. Hasil analisis menunjukkan bahwa terjadi peningkatan produktivitas rata-rata perikanan budi daya air tawar di tujuh belas DMU sebesar $12 \%$ pada periode 2013 - 2017 yang ditunjukkan dengan nilai rata - rata indeks malmquist 1,12. Tabel 4 juga menunjukkan hasil perhitungan dengan DEAMalmquist bahwa nilai rata -rata indeks malmquist selama lima tahun di tujuh belas DMU antara 0,82-1,82. Perhitungan DEA menunjukkan bahwa 53\% DMU yang mengalami peningkatan produktivitas atau mempunyai nilai indeks Malmquist > 1, meliputi Bali $(1,82)$, Gorontalo $(1,13)$, Jawa Timur $(1,10)$, Kalimantan Timur (1,30), Kepulauan Bangka Belitung (1,13), Maluku Utara (1,53), Nusa Tenggara Barat $(1,51)$, Sulawesi Barat $(1,08)$, dan Sulawesi Tengah $(1,56)$. Selain itu, perubahan produktivitas rata - rata perikanan budi daya air tawar terbesar terjadi tahun 2015-2016, yaitu sebesar 33\% dengan nilai indeks malmquist sebesar 1,33. Peningkatan produktivitas ini dipengaruhi oleh peningkatan efisiensi sebesar $14 \%$ dengan nilai catch up 1,14 dan pengaruh perubahan penggunaan teknologi sebesar $17 \%$ dengan frontier shift 1,17. Artinya, pemerintah pada tahun 2015 yang mulai mendorong pengembangan teknologi intensifikasi di masyarakat, seperti bioflok untuk komoditas lele dan nila berpengaruh positif terhadap terciptanya efisiensi dan peningkatan

Tabel 4. Nilai Indeks Malmquist Kinerja Perikanan Budi Daya Air Tawar di Indonesia Tahun 2013 - 2017.

\begin{tabular}{|c|c|c|c|c|c|c|}
\hline \multirow{2}{*}{ No } & \multirow{2}{*}{ DMU } & \multicolumn{4}{|c|}{ Indeks Malmquist } & \multirow{2}{*}{$\begin{array}{c}\text { Rata-rata } \\
\text { 2013-2017 }\end{array}$} \\
\hline & & $2013-2014$ & 2014-2015 & 2015-2016 & 2016-2017 & \\
\hline 1 & Bali & 1,21 & 0,99 & 1,43 & 6,47 & 1,82 \\
\hline 2 & Banten & 0,97 & 0,95 & 1,10 & 0,67 & 0,91 \\
\hline 3 & Gorontalo & 1,11 & 1,04 & 1,39 & 1,04 & 1,13 \\
\hline 4 & Jawa Barat & 0,74 & 1,15 & 1,19 & 0,86 & 0,97 \\
\hline 5 & Jawa Tengah & 1,10 & 0,66 & 1,52 & 0,42 & 0,82 \\
\hline 6 & Jawa Timur & 1,09 & 1,09 & 1,08 & 1,14 & 1,10 \\
\hline 7 & Kalimantan Timur & 0,36 & 0,66 & 16,02 & 0,74 & 1,30 \\
\hline 8 & Kep Babel & 1,04 & 1,11 & 1,18 & 1,19 & 1,13 \\
\hline 9 & Lampung & 0,87 & 0,76 & 1,29 & 0,77 & 0,90 \\
\hline 10 & Maluku Utara & 1,31 & 0,37 & 1,03 & 10,86 & 1,53 \\
\hline 11 & NTB & 1,09 & 0,99 & 1,30 & 3,66 & 1,51 \\
\hline 12 & NTT & 0,69 & 1,03 & 1,60 & 0,76 & 0,97 \\
\hline 13 & Papua Barat & 1,45 & 0,41 & 0,97 & 1,31 & 0,93 \\
\hline 14 & Sulawesi Barat & 1,07 & 1,98 & 0,89 & 0,74 & 1,08 \\
\hline 15 & Sulawesi Selatan & 1,27 & 1,03 & 1,19 & 0,63 & 1,00 \\
\hline 16 & Sulawesi Tengah & 0,99 & 1,25 & 1,06 & 4,53 & 1,56 \\
\hline 17 & Sumatera Utara & 1,04 & 1,44 & 0,56 & 1,06 & 0,97 \\
\hline & Rerata & 0,98 & 0,92 & 1,33 & 1,32 & 1,12 \\
\hline
\end{tabular}

Sumber: Data sekunder diolah, 2019 
produktivitas. Penggunaan teknologi bioflok mampu menekan FCR pakan, dan dapat dilakukan dalam kepadatan tinggi dengan lingkungan terkontrol sehingga meningkatkan survival rate (SR) (KKP, 2018c). Hasil penelitian juga mengidentifikasi DMU yang mengalami peningkatan produktivitas paling besar pada setiap perubahan antar waktu yang terjadi pada tahun 2013 sampai dengan 2017 secara berurut-urut, yaitu Provinsi Jawa Barat $(6,24)$, Sulawesi Barat $(5,05)$, Kalimantan Timur $(4,53)$, dan Sulawesi Tengah $(4,55)$.

Selain terjadi peningkatan pada produktivitas, berdasarkan Tabel 4 juga terjadi penurunan produktivitas sebesar $2 \%$ dan $8 \%$ terjadi pada periode 2013 - 2014 dan 2014 - 2015 yang ditunjukkan dengan nilai rata-rata indeks malmquist 0,98 dan $0,92(<1)$. Penurunan produktivitas yang terjadi diakibatkan oleh usaha perikanan budi daya air tawar yang dilakukan sebagian besar belum efisien karena intensifikasi yang dilakukan berpengaruh terhadap kenaikan kebutuhan input pakan yang harganya sangat mahal, sedangkan margin keuntungan usaha budi daya ikan air tawar relatif kecil apabila dibandingkan dengan usaha budi daya ikan air laut dan air payau. Oleh karena itu, salah satu kebijakan yang perlu persiapkan adalah fokus pada pengembangan komoditas ikan air tawar yang memiliki daya saing tinggi di pasar domestik maupun internasional dan mempertimbangkan daya dukung wilayahnya, contohnya ikan nila (Oktopura, Fauzi, Sugama, \& Mulyati, 2020).

\section{PENUTUP}

Perspektif multistakeholder dalam penelitian ini menemukan 6 permasalahan pada dimensi lingkungan, 7 permasalahan pada dimensi ekonomi, dan 4 permasalahan pada dimensi sosial yang berpotensi menghambat pencapaian optimalisasi pembangunan perikanan budi daya secara berkelanjutan di masa mendatang apabila tidak diselesaikan dengan baik. Nilai rata-rata tingkat efisiensi pembangunan perikanan budi daya laut, air payau, dan air tawar di tujuh belas DMU selama lima tahun sebesar 43\%, 36\%, dan $49 \%$ atau kurang dari $100 \%$, menunjukan bahwa efisiensi kinerja pembangunan perikanan budi daya di sebagian besar wilayah DMU pada tiga tipologi ekosistem, yaitu laut, payau, dan tawar belum optimal dilaksanakan. Nilai indeks malmquist lebih besar dari satu untuk budi daya laut, air payau, dan air tawar, yaitu 1,08, 1,43, dan 1,12 , menunjukan bahwa terjadi peningkatan produktivitas sebesar $8 \%-43 \%$ pada ketiga tipologi budi daya.

Pada kurun waktu tahun 2013 - 2017, kinerja pembangunan perikanan budi daya nasional belum optimal, tetapi berpotensi untuk ditingkatkan pada masa mendatang apabila didukung dengan implementasi kebijakan dan strategi yang tepat. Oleh karena itu, ada tujuh opsi kebijakan dan strategi yang dapat direkomendasikan untuk meningkatkan kinerja pembangunan perikanan budi daya di semua tipologi ekosistem pada masa datang, yaitu (1) Peningkatan kapasitas manajerial dan pengetahuan pembudi daya ikan melalui sosialisasi teknologi, pelatihan, dan pendampingan teknis; (2) Penyediaan input produksi yang bermutu dengan harga yang terjangkau; (3) Perluasan pasar mutu produk dan nilai tambah; (4) Perbaikan sistem rantai pasok usaha perikanan budi daya; (5) Peningkatan skala usaha melalui intensifikasi teknologi; (6) Penelitian dan perekayasaan untuk pengembangan inovasi teknologi; serta (7) Penguatan regulasi dan simplifikasi perizinan yang terkait usaha perikanan budi daya. Peran dan keterlibatan dari multistakeholder, antara lain pemerintah pusat, pemerintah daerah, peneliti, akademisi, penyuluh, asosiasi pelaku usaha di sektor perikanan budi daya, pembudi daya ikan, pedagang atau eksportir, dan lembaga keuangan diperlukan dalam implementasi strategi-strategi ini agar mencapai hasil yang optimal.

\section{UCAPAN TERIMA KASIH}

Penulis mengucapkan terima kasih kepada semua dosen pembimbing yang telah memberikan masukan dan mendorong saya untuk menyelesaikan penelitian ini dengan baik. Ucapan terima kasih juga kepada teman - teman di Bagian Program Ditjen Perikanan Budi Daya, dan Balai Besar Riset Sosial Ekonomi Kelautan dan Perikanan, BRSDM KP, KKP yang telah membantu dalam penyediaan data dan memberikan masukan terkait penulisan ini.

\section{PERNYATAAN KONTRIBUSI PENULIS}

Dengan ini saya yang bernama Andy Artha Donny Oktopura adalah kontributor utama dalam pelaksanaan penelitian dan penulisan paper ini di bawah supervisi Prof. Akhmad Fauzi Ph.D. dan Prof. Dr. Ketut Sugama sebagai kontributor utama, serta Dr. Heti Mulyati S.T.P, M.T. sebagai kontributor anggota makalah ini. 


\section{DAFTAR PUSTAKA}

Aisya, L. K., Koeshendrajana, S., \& Iqbal, M. (2005). Analisa Daya Saing Ekspor Produk Perikanan Indonesia: Pendekatan Model Revealed Comparative Advantage (RCA) dan Constant Market Share Analysis (CMSA). Jurnal Penelitian Perikanan Indonesia, 11(9): 97-104. doi: http:// dx.doi.org/10.15578/jppi.11.9.2005.97-104

Alam, M. F. (2011). Measuring Technical, Allocative, and Cost Efficiency of Pangas (Pangasius hypophthalmus: Sauvage 1878) Fish Farmers of Bangladesh. Aquaculture Research, 42 (10), 1487-1500. doi: https://10 .1111/j.1365-2109.2010.02741

Asche, F., Roll, K. H. \& Tveteras, R. (2007). Productivity Growth in the Supply Chain-Another Source of Competitiveness for Aquaculture. Marine Resource Economics, 22, 329-334. https://core. ac.uk/download/pdf/7075793.pdf

[BPS] Badan Pusat Statistik. (2019). Data Statistik Indonesia 2018. diperoleh dari www.bps.go.id

Charnes, A., Cooper, W. W., \& Rhodes, E. (1981). Evaluating program and managerial efficiency: an application of data envelopment analysis to program follow through. Management Science, 27(6), 668-697. doi: http://dx.doi.org/10.1287/ mnsc.27.6.668

Coelli, T. J., Rao, D. S. P., O’Donnell, C. J., \& Battese, G. E. (2005). An Introduction to Efficiency and Productivity Analysis. 2nd Edition. New York. USA: Springer

Dahuri, R. (2018). Pembangunan ekonomi kelautan untuk peningkatan daya saing dan pertumbuhan ekonomi berkualitas secara berkelanjutan menuju Indonesia yang maju, sejahtera, dan berdaulat. Paper pada Seminar Tantangan Kelautan Dalam Pencapaian SDGs di Bidang Kelautan. Bandung ID: Universitas Padjajaran

[FAO] Food and Agriculture Organization. (2016). The state of the world fisheries and aquaculture. Contributing to food security and nutrition for all. Rome. ITA: FAO

Fare, R., Grosskopf, S., Lindgren, B., \& Roos, P. (1994). Productivity developments in Swedish hospitals: A malmquist output index approach. Data envelopment analysis: Theory, methodology, and applications. Dordrecht. NED: Spinger

Farrell, M. J. (1957). Measurement of productive efficiency. Journal of Royal Statistical Society, 120, 253-290. doi: https://doi.org/10.2307/2343100

Fauzi, A. (2010). Ekonomi Perikanan: Teori, Kebijakan, dan Pengelolaan. Jakarta. ID: PT. Gramedia Pustaka Utama
Hishamunda, N., Cai, J., \& Leung, P. S. (2009). Commercial Aquaculture and Economic Growth, Poverty Allevation and Food Security. Rome, ITA: FAO

Hussain, A \& Jones, M. (2018). An introduction to frontier analyst@4. Diperoleh dari www.banxia.com

Iliyasu, A., Mohamed, A. Z., Ismail, M. M., Abdullah, A. M., Kamarudin, S. M., \& Mazuki, H. (2014). A review of production frontier research in aquaculture (2001-2011). Aquaculture Economics \& Management, 18(3), 221-247. doi: https://10.10 80/13657305.2014.926464

Iliyasu, A., Mohamed, Z. A., \& Hashim, M. (2015). Productivity growth, technical change and efficiency change of the Malaysian cage fish farming: An application of Malmquist Productivity Index approach. Aquaculture International, 23(4), 1013-1024. doi: https://10.1007/ s10499.014.9860-9

Imamah, I. L., Hartoyo, S., Syaukat, Y., \& Utami, K. P. (2013). Total faktor produktivitas usaha tambak terkait dengan polutan tambak di Kabupaten Karawang. Jurnal Agribisnis, 7(1), 35-58. doi: https://doi.org/10.15408/aj.v7i1.5169

Juarno, O., Oktaviani, R., Fauzi, A., \& Nuryartono, N. (2011). Kinerja produktivitas dan faktor yang berpengaruh terhadap Total Factor Productivity (TFP) Tambak Udang di Indonesia. Jurnal Sosial Ekonomi Kelautan dan Perikanan, 6(2), 149 - 168. doi: http://dx.doi.org/10.15578/jsekp. v6i2.5770

[KKP] Kementerian Kelautan dan Perikanan. (2005). Laporan hasil survei sosial ekonomi profil pelaku usaha pembudi dayan ikan. Jakarta. ID: DJPB. KKP

[KKP] Kementerian Kelautan dan Perikanan. (2018a). Kelautan dan perikanan dalam angka Tahun 2012 - 2017. Jakarta, ID: Pusdatin. KKP

[KKP] Kementerian Kelautan dan Perikanan. (2018b). Masterplan pembangunan perikanan budi daya 2020 - 2024. Jakarta, ID: DJPB KKP

[KKP] Kementerian Kelautan dan Perikanan. (2018c). Laporan analisa dampak kegiatan prioritas. Jakarta, ID: DJPB KKP

[KKP] Kementerian Kelautan dan Perikanan. (2019). Laporan kinerja Direktorat Jenderal Perikanan Budidaya Tahun 2018. Jakarta, ID: KKP

Koeshendrajana, S., Suryawati, S. H., Saptanto, S., \& Nasution, Z. (2004). Identifikasi indikator kinerja pengelolaan perikanan budidaya yang berrsifat lestari. Jurnal Penelitian Perikanan Indonesia, 10(7), 55-66. doi: http://dx.doi.org/10.15578/ jppi.10.7.2004.55-66 
Manjarrez, A. J., Soto, D., \& Brummett, R. (2017). Aquaculture zoning, site selection and area management under ecosystem approach to aquaculture. Washington DC: FAO and World Bank Group

Mustapha, N. H. N, Azis, A. A, Hashim, N. M. H. (2013). Technical efficiency in aquaculture industry using Data Envelopment Analysis (DEA) window: Evidence from Malaysia. Journal of Sustainability Science and Management, 8(2), 137 - 149. doi: http://jssm.umt.edu.my/files/2013/12/1W2.pdf

Ngoc, P. T. A., Gaitan-Cremaschi, D., Meuwissen, M. P. M., Le, T. C., Bosma, R. H., Verreth, J., \& Lansink, A. O. (2018). Technical inefficiency of Vietnamese pangasius farming: A data envelopment analysis. Aquaculture Economics and Management, 22(2), 229-243. doi: https://10.1080/13657305.2017.1 399296

Oktopura, A. A. D., Fauzi, A., Sugama, K., Mulyati, H. (2020). Determination of aquaculture priority commodities based on market competitiveness using multiple tool analysis. AACL Bioflux, 13(1), 439-449. doi: http://www.bioflux.com.ro/ docs/2020.439-449.pdf

Ozbugday, F. C., Tirgil, A., \& Kose, E. G., (2019). Efficiency changes in long-term care in OECD countries: A non-parametric Malmquist Index approach. Socio-Economic Planning Sciences, Elsevier, 70(C). doi: https://doi.org/10.1016/j. seps.2019.100733

Phillips, M., Henriksson, P. J. G., Tran, N., Chan, C. Y., Mohan, C. V., Rodriguez, U. P., Suri, S., Hall, S., \& Koeshendrajana, S. (2016). Menjelajahi masa depan perikanan budi daya Indonesia. Penang, MAS: World Fish Center

Rahman, M. T., Nielsen, R., Khan, M. A., Asmild, M. (2019). Efficiency and Production Environmental Heterogeneity inAquaculture:AMeta-Frontier DEA Approach. Aquaculture, 509, 140-148. doi: https:// doi.org/10.1016/j.aquaculture.2019.05.002

Rizal, A. (2013). Kinerja Sektor Perikanan Provinsi Banten. Jurnal Akuatika, 1, 21-34. doi: http:// jurnal.unpad.ac.id/akuatika/article/view/2615

Rizal, A, Iskandar, Heti, H., \& Lantun, P. D. (2018). Potret dan review strategi pembangunan perikanan dan kelautan Indonesia. Bandung, ID: Unpad Press

Rusydiana, A. S. (2018). Indeks Malmquist untuk pengukuran efisiensi dan produktivitas bank syariah dl Indonesia. Jurnal Ekonomi dan Pembangunan, 26(1), 47 - 58. doi: https://doi. org/10.14203/JEP.26.1.2018.47-58

Sharma, K. R. \& Leung, P. S. (2000). Technical Efficiency of Carp Pond Culture in South Asia: An Application of A stochastic Meta-pro- duction Frontier Model. Aquaculture Economic Management, 4(3-4), 169-189. doi: https://doi. org/10.1080/13657300009380268

Suryana, A. A. H., Fauzi, A., Juanda, B., \& Rustiadi E. (2014). Dinamika Interspatial Total Factor Productivity Usaha Perikanan Budi daya Air Tawar dan Implikasinya Terhadap Perekonomian Wilayah Jawa Barat. Jurnal Sosiohumaniora, 16(1), 89 - 94. doi: https://10.24198/sosiohumaniora.v16i1.5688

Tacon, A. G. J. (2001). Increasing the Contribution of Aquaculture for Food Security and Poverty Alleviation. Technical Proceedings of the Conference on Aquaculture in the Third Millennium. Bangkok, 20 - 25 February 2000. Bangkok, THA: NACA and FAO

Tajerin \& Noor, M. (2005). Analisis Efisiensi Teknis Usaha Budi daya Pembesaran Ikan Kerapu dalam Keramba Jaring Apung di Perairan Teluk Lampung: Produktivitas, Faktor-Faktor yang Mempengaruhi dan Implikasi Kebijakan Pengembangan Budi dayanya. Jurnal Ekonomi Pembangunan, 10(1), 95 - 105. doi: https://doi. org/10.20885/vol10iss1aa608

Tajerin. (2007). Efisiensi teknis usaha budi daya udang di lahan tambak dengan teknologi intensifikasi pembudi dayaan ikan. Jurnal IImu-ilmu Perairan dan Perikanan Indonesia, 14 (1), 1-11. doi: http:// journal.ipb.ac.id/index.php/jippi/issue/view/770

[USAID] United States Agency for International Development. (2006). A Pro-Poor Analysis of the Shrimp Sector in Bangladesh. Greater Access to Trade Expantsion (GATE) Project for the U.S. Agency for International Development. Arlington, USA: USAID

Valderrama, D \& Engle R.C. (2004). Farm Level Economic Effects of Viral Diseases on Honduran Shrimp Farms. Journal of Applied Aquaculture, 16(1-2), 1-26. doi: http://dx.doi.org/10.1300/ J028v16n01_01

Wardono, B., Fauzi, A., Fahrudin, A., \& Purnomo, A. H. (2015). Total faktor produktivitas dan indeks instabilitas perikanan tangkap: Kasus di Pelabuhan Ratu, Jawa Barat. Jurnal Sosial Ekonomi Kelautan Perikanan, 10(1), 35 - 46. doi: http://dx.doi.org/10.15578/jsekp.v10i1.1246

World Bank. (2007). Changing the Face of Water, the Promise and Challenge of Sustainable Aquaculture. Washington DC, USA: World Bank 